[Agr. Biol. Chem., Vol. 36, No. 13, p. 2523 2528, 1972]

\title{
Synthesis of L-Tryptophan from Pyruvate, Ammonia and Indole ${ }^{\dagger}$
}

\author{
By Hidetsugu Nakazawa, Hitoshi Ener, Shinji Okumura \\ and Hideaki YamadA*
}

\author{
Central Research Laboratories, Ajinomoto Co., Inc., \\ Kawasaki, Japan \\ * Research Institute for Food Science, \\ Kyoto University, Kyoto, Japan
}

Received July 20, 1972

\begin{abstract}
The tryptophanase activity which synthesizes L-tryptophan from pyruvate, ammonia and indole, was found to be widely distributed in cells of bacteria belonging to Enterobacteriaceae, such genera as Escherichia, Kluyvera, Enterobacter, Erwinia and Proteus. With the cells of Proteus rettgeri, equilibrium of the elimination reaction of L-tryptophan in the presence of high concentration of ammonia was studied. It was found that the equilibrium inclines toward the synthetic state.

When 5-hydroxy- and 5-methyl-indole were substituted for indole, 5-hydroxy- and 5methyl-L-tryptophan, respectively, were synthesized. The synthesis of L-tryptophan was also observed with indole and various amino acids, S-methyl-L-cysteine, S-ethyl-L-cysteine, Lcysteine, 5-fluoro-DL-tryptophan, or oxalacetic acid.
\end{abstract}

Tryptophanase is an enzyme which catalyzes the stoichiometric conversion of L-tryptophan to pyruvate, ammonia and indole (reaction [1]), and requires pyridoxal phosphate as a cofactor. ${ }^{11}$ A homogeneous preparation of the enzyme has been prepared by Newton et al. ${ }^{2,3)}$ from Escherichia coli.

$$
\begin{aligned}
& \text { L-Tryptophan }+\mathrm{H}_{2} \mathrm{O} \rightarrow \\
& \quad \mathrm{CH}_{3} \mathrm{COCOOH}+\mathrm{NH}_{3}+\text { indole }
\end{aligned}
$$

They reported that the crystalline preparation of enzyme catalyzes a series of $\alpha, \beta$-elimination [2] and $\beta$-replacement [3] reactions.

$$
\begin{gathered}
\mathrm{R}_{\mathrm{I}} \mathrm{CH}_{2} \mathrm{CHNH}_{2} \mathrm{COOH}+\mathrm{H}_{2} \mathrm{O} \rightarrow \\
\mathrm{R}_{\mathrm{I}} \mathrm{H}+\mathrm{CH}_{3} \mathrm{COCOOH}+\mathrm{NH}_{3} \\
\mathrm{R}_{\mathrm{I}} \mathrm{CH}_{2} \mathrm{CHNH}_{2} \mathrm{COOH}+\mathrm{R}_{\mathrm{II}} \mathrm{H} \rightarrow \\
\mathrm{R}_{\mathrm{II}} \mathrm{CH}_{2} \mathrm{CHNH}_{2} \mathrm{COOH}+\mathrm{R}_{\mathrm{I}} \mathrm{H}
\end{gathered}
$$

In reactions of [2] and [3], $\mathrm{R}_{\mathrm{I}}$ may represent $-\mathrm{OH},-\mathrm{OCH}_{3},-\mathrm{SH},-\mathrm{SCH}_{3}$ or indolyl radicals and $\mathrm{R}_{\mathrm{II}}$ represents indolyl radicals.

$\dagger$ Bacterial Synthesis of L-Tryptophan and Its Analogues, Part I.
Subsequent to these investigations, we $\mathrm{e}^{4 \sim 8)}$ showed that $\beta$-tyrosinase from Escherichia intermedia and Erwinia herbicola catalyzes the conversion of L-tyrosine to pyruvate, ammonia and phenol (reaction [4]), but not that of L-tryptophan.

$$
\begin{aligned}
& \text { L-Tyrosine }+\mathrm{H}_{2} \mathrm{O} \rightarrow \\
& \quad \mathrm{CH}_{3} \mathrm{COCOOH}+\mathrm{NH}_{3}+\text { phenol }
\end{aligned}
$$

It catalyzes a series of $\alpha, \beta$-elimination [5] and $\beta$-replacement [6] reactions, by a similar reaction mechanism as that of tryptophanase.

$$
\begin{array}{r}
\mathrm{R}_{\mathrm{III}} \mathrm{CH}_{2} \mathrm{CHNH}_{3} \mathrm{COOH}+\mathrm{H}_{2} \mathrm{O} \rightarrow \\
\mathrm{R}_{\mathrm{III}} \mathrm{H}+\mathrm{CH}_{3} \mathrm{COCOOH}+\mathrm{NH}_{3} \\
\mathrm{R}_{\mathrm{III}} \mathrm{CH}_{2} \mathrm{CHNH} \mathrm{CHOOH}_{2} \mathrm{COO} \mathrm{R}_{\mathrm{IV}} \mathrm{H} \rightarrow \\
\mathrm{R}_{\mathrm{III}} \mathrm{H}+\mathrm{R}_{\mathrm{IV}} \mathrm{CH}_{2} \mathrm{CHNH} \mathrm{CHOH}_{2} \mathrm{COOH}
\end{array}
$$

In reactions of [5] and [6], $R_{\text {III }}$ represents $-\mathrm{OH},-\mathrm{SH}$, or phenolyl radicals, and $\mathrm{R}_{\mathrm{IV}}$ phenolyl radicals. We $e^{9)}$ also showed that $\beta$ tyrosinase catalyzes the synthesis of L-tyrosine from pyruvate, ammonia and phenol, ap- 
parently by the reversal of $\alpha, \beta$-elimination reaction.

In appropriate studies, it has recently been proved that the crystalline tryptophanase from E. coli ${ }^{10)}$ and Proteus rettger $i^{11)}$ also catalyzes the synthesis of L-tryptophan by the reversal of $\alpha, \beta$-elimination reaction, at rates similar to the forward reaction.

On the basis of these findings, an investigation has been undertaken in our laboratory, for preparation of L-tryptophan or its analogues from pyruvate, ammonia and indole or its analogues, respectively. The present paper describes the distribution of tryptophanase activity in bacteria, and some catalytic properties of the enzyme in Proteus rettgeri.

\section{EXPERIMENTAL PROCEDURE}

Reagents. 5-Hydroxyindole was purchased from Aldrich Chemical Co. Inc. 5-Methylindole was a gift from Dr. Y. Kanaoka, Hokkaido University, Sapporo, Japan. Pyridoxal phosphate was purchased from Sigma Chemical Company. Other chemicals used in this work were commercial products.

Cultural conditions. The bacterial cells used were preserved in the Central Research Laboratories, Ajinomoto Co. Inc. The cells were grown at $31.5^{\circ} \mathrm{C}$ for $16 \mathrm{hr}$ on the agar slants of a medium containing $1.0 \%$ yeast extract, $1.0 \%$ polypeptone, $0.5 \% \mathrm{KCl}$ and $0.2 \% \mathrm{~L}$-tryptophan. The cells grown on the slants were used for the study on the distribution of tryptophanase activity in bacteria.

The cells of Proteus rettgeri AJ 2770 which were selected for the likely source of tryptophanase were grown in a medium consisting of $0.2 \%$ L-tryptophan, $2 \%$ soybean protein hydrolyzate, $5 \%$ corn steep liquor, $0.17 \% \mathrm{~L}$-alanine, $0.17 \% \mathrm{~L}$-isoleucine, $0.17 \% \mathrm{~L}$-tyrosine, $0.17 \%$ L-histidine, $0.1 \%$ succinic acid, $0.17 \%$ citric acid, $0.01 \%$ pyridoxine- $\mathrm{HCl}, 0.05 \% \mathrm{MgSO}_{4} \cdot 7 \mathrm{H}_{2} \mathrm{O}$ and $0.2 \% \mathrm{KH}_{2} \mathrm{PO}_{4}$ in tap water $(\mathrm{pH} 6.0)$. The culture was carried out at $31.5^{\circ} \mathrm{C}$ for $16 \mathrm{hr}$ in $500 \mathrm{ml}$-shaking flasks containing $60 \mathrm{ml}$ of the medium, under shaking. The cells grown in the medium were harvested and directly used as enzyme for the study on the enzymatic synthesis of L-tryptophan and its analogues.

Assay conditions. Tryptophanase activity was determined by measuring the amount of L-tryptophan synthesized from pyruvate, ammonia and indole in a reaction mixture containing $20 \mathrm{mg}$ of sodium pyruvate, $20 \mathrm{mg}$ of indole, $50 \mathrm{mg}$ of ammonium acetate, $1 \mathrm{mg}$ of $\mathrm{Na}_{2} \mathrm{SO}_{3}, 3 \mathrm{mg}$ of EDTA, $0.1 \mathrm{mg}$ of pyridoxal phosphate and $4 \mathrm{mg}$ of cells as dried matter, in a total volume of $1.0 \mathrm{ml}$. After $\mathrm{pH}$ was adjusted to 9.0 by $6 \mathrm{~N} \mathrm{KOH}$, the mixture was incubated at $37^{\circ} \mathrm{C}$ for $16 \mathrm{hr}$.

Analytical methods. (a) L-Tryptophan, 5-hydroxyL-tryptophan and 5-methyl-L-tryptophan were qualitatively detected by paper chromatography with a solvent system of $n$-propanol-ammonia-water (20:15:3). These amino acids were detected under ultraviolet light and by spray with ninhydrin or Ehrich's reagents. ${ }^{12}$

(b) These amino acids were determined using paper chromatography, followed by the absorbance measurement. A definite amount, $10 \mu 1$, of the reaction mixture was applied on a filter paper and developed as described above. The spot of the amino acids was eluted from the paper chromatogram with $5 \mathrm{ml}$ of $0.1 \mathrm{~N} \mathrm{HCl}$ and the amount of the amino acids was estimated spectrophotometrically by measuring the absorbance at $280 \mathrm{~m} \mu$.

(c) Pyruvate was determined by the method of Friedemann and Haugen. ${ }^{13 !}$

\section{RESULTS AND DISCUSSION}

Distribution of tryptophanase activity in bacteria Tryptophanase activity in 1138 strains of bacteria was assayed by measuring the amount of L-tryptophan synthesized from pyruvate, ammonia and indole. It was found that the enzyme activity was widely distributed in bacteria belonging to Enterobacteriaceae, such genera as Escherichia, Kluyvera, Enterobacter, Erwinia and Proteus, as given in Table I. The amount of L-tryptophan synthesized by the cells of 40 strains was shown in Table II.

\section{Isolation and identification of the reaction product}

A reaction mixture contained $30 \mathrm{~g}$ of sodium pyruvate, $20 \mathrm{~g}$ of indole, $50 \mathrm{~g}$ of ammonium acetate, $1 \mathrm{~g}$ of $\mathrm{Na}_{2} \mathrm{SO}_{3}, 3 \mathrm{~g}$ of EDTA, $0.1 \mathrm{~g}$ of pyridoxal phosphate and $4 \mathrm{~g}$ of cells Proteus rettgeri in a total volume of $1,000 \mathrm{ml}$. After 
Table I. Distribution of Tryptophanase IN BACTERIA a)

\begin{tabular}{|c|c|c|}
\hline Genus & $\begin{array}{c}\text { No. of strains } \\
\text { tested }\end{array}$ & $\begin{array}{l}\text { No. of strains } \\
\text { synthesizing } \\
\text { L-tryptophan }\end{array}$ \\
\hline Pseudononas & 475 & 0 \\
\hline Xanthomonas & 19 & 0 \\
\hline Acetobacter & 79 & 0 \\
\hline Aeromonas & 7 & 0 \\
\hline Mycoplana & 5 & 0 \\
\hline Vibrio & 4 & 0 \\
\hline Azotobacter & 6 & 0 \\
\hline Rhizobitum & 14 & 0 \\
\hline Agrobacterium & 6 & 0 \\
\hline Alcaligenes & 54 & 0 \\
\hline Achromobacter & 61 & 0 \\
\hline Flavobacterium & 89 & 0 \\
\hline Escherichia & 44 & 8 \\
\hline Kluyvera & 5 & 2 \\
\hline Enterobacter & 65 & 12 \\
\hline Erwinia & 131 & 8 \\
\hline Serratia & 44 & 0 \\
\hline Proteus & 14 & 10 \\
\hline Salmonella & 7 & 0 \\
\hline Clostridium & 9 & 0 \\
\hline Total & 1138 & 40 \\
\hline
\end{tabular}

$\mathrm{pH}$ was adjusted to 9.0 with $6 \mathrm{~N} \mathrm{KOH}$, the mixture was incubated at $37^{\circ} \mathrm{C}$ for $48 \mathrm{hr}$. Under these conditions, approx. $23 \mathrm{~g}$ of tryptophan was synthesized in the mixture based on paper chromatographic analysis. The tryptophan synthesized was isolated by a procedure given, in Fig. 1, yielding colorless crystals. The crystals were identical with authentic L-tryptophan, in respects of melting point, IR- (Fig. 2) and NMR- (Fig. 3) spectra, optical activity and elementary analysis (Table III).

Apparent equilibrium of elimination reaction by cells of Proteus rettgeri

$\alpha, \xi$-Elimination reaction [1] catalyzed by tryptophanase is shown to be reversible. ${ }^{10,11)}$ Then, an apparent equilibrium of the elimina-
TABle II. SYNTHESIS OF L-TRYPTOPHAN BY Cells of Bacteria Belonging to ENTEROBACTERIACEAE ${ }^{a}$

\begin{tabular}{|c|c|c|c|}
\hline & \multicolumn{2}{|c|}{$\begin{array}{l}\text { Strain } \\
\text { tested }\end{array}$} & $\begin{array}{l}\text { L-Tryptophan } \\
\text { synthesized } \\
(\mathrm{mg} / \mathrm{ml})\end{array}$ \\
\hline Escheric & hia coli AT & $\mathrm{rCC}$ & 3 \\
\hline$" \prime$ & " $\mathrm{AT}$ & $\Gamma \mathrm{CC}$ & 2 \\
\hline$"$ & AT & TCC 3655 & 1 \\
\hline , & " $\mathrm{AT}$ & ICC 7009 & 1 \\
\hline$"$ & AT & rCC 10798 & 5 \\
\hline$" 1$ & " $\mathrm{AJ}$ & 2594 & 2 \\
\hline " & $\mathrm{AJ}$ & 2595 & 2 \\
\hline$"$ & " $\mathrm{AJ}$ & 2597 & 3 \\
\hline Kllyver & a citrophila & AJ 2626 & 2 \\
\hline " & $\prime \prime$ & AJ 2628 & 2 \\
\hline Enterob & acter aeroge & enes ATCC 8329 & 9 \\
\hline " & $"$ & ATCC 8724 & 11 \\
\hline " & liquefacien & AJ 2661 & 10 \\
\hline " & (sp.) & AJ 3044 & 7 \\
\hline " & $"$ & AJ 3047 & 7 \\
\hline " & $" r$ & AJ 3049 & 8 \\
\hline$" 7$ & $"$ & AJ 3051 & 8 \\
\hline$"$ & $"$ & AJ 3053 & 1 \\
\hline , & " & AJ 3054 & 1 \\
\hline " & " & AJ 3055 & 3 \\
\hline$" \prime$ & " & AJ 3056 & 1 \\
\hline$"$ & $"$ & AJ 3080 & 9 \\
\hline Erwinia & herbicola & AJ 2973 & 1 \\
\hline$" \prime$ & " & ATCC 23822 & 1 \\
\hline Erwinia & carotovora & AJ 2753 & 1 \\
\hline$"$ & $"$ & AJ 2754 & 3 \\
\hline " & " & AJ 2947 & 4 \\
\hline " & $"$ & AJ 2950 & 3 \\
\hline " & " & AJ 2979 & 1 \\
\hline$"$ & " & AJ 2983 & 1 \\
\hline Proteus & rettgeri & AJ 2768 & 10 \\
\hline$"$ & , & AJ 2769 & 10 \\
\hline " & $"$ & AJ 2770 & 15 \\
\hline " & morganii & IFO 3848 & 3 \\
\hline$"$ & vulgaris & AJ 2764 & 4 \\
\hline " & $"$ & AJ 2765 & 4 \\
\hline$"$ & " & AJ 2766 & 4 \\
\hline$"$ & " & AJ 2767 & 4 \\
\hline$"$ & " & AKU 0082 & 5 \\
\hline$"$ & (sp.) & & 10 \\
\hline
\end{tabular}

a) The assay conditions were fully described in the text.

tion reaction of L-tryptophan by the cells of Proteus rettgeri with higher tryptophanase 
Reaction mixture (1 liter)

- concentrated in vacuo

-adjusted $\mathrm{pH}$ to 1.0 with conc. $\mathrm{HCl}$

- centrifuged to separated bacterial cells and residual indole

\section{Supernatant}

- concentrated in vacuo

- adsorbed on active charcoal

-eluted with $0.1 \mathrm{~N} \mathrm{HCl}$

-washed with water

-eluted with $0.3 \mathrm{~N} \mathrm{NH}_{4} \mathrm{OH}$

\section{Elute}

- concentrated in vacuo

-adjusted $\mathrm{pH}$ to 5.9 with $6 \mathrm{~N} \mathrm{HCl}$

\section{Crystals}

\section{Recrystals}

FIG. 1. Isolation of the Reaction Product.
Table III. Properties of L-Tryptophan

\begin{tabular}{lcrcc}
\hline \multirow{2}{*}{ L-Tryptophan } & Optical activity & \multicolumn{4}{c}{ Elemental analyses } \\
& {$[\alpha]_{\mathrm{D}}^{23}\left(c=0.5\right.$ in $\left.\mathrm{H}_{2} \mathrm{O}\right)$} & $\mathrm{C}$ & $\mathrm{H}$ & $\mathrm{N}$ \\
\hline Isolated & -31.0 & 64.9 & 6.0 & 14.0 \\
Authentic & -31.0 & 64.8 & 5.9 & 13.7
\end{tabular}

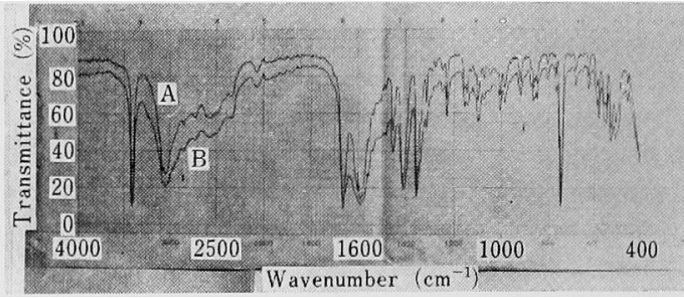

FIG. 2. Infrared Absorption Spectra of Authentic (A) and Isolated L-Tryptophan (B).

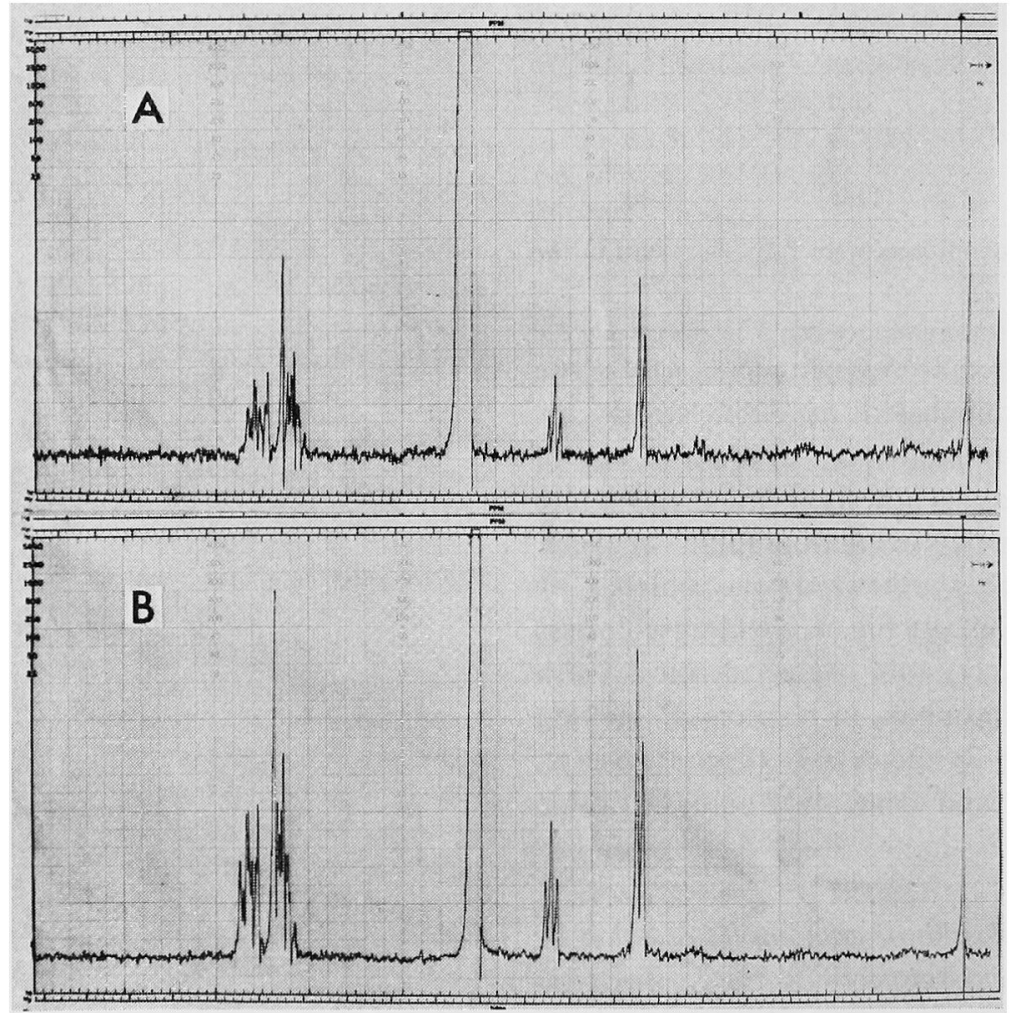

FIG. 3. NMR Spectra of Authentic (A) and Isolated L-Tryptophan (B).

The spectra were recorded with a Varian A-60 NMR spectrometer with DDS as the internal standard. 


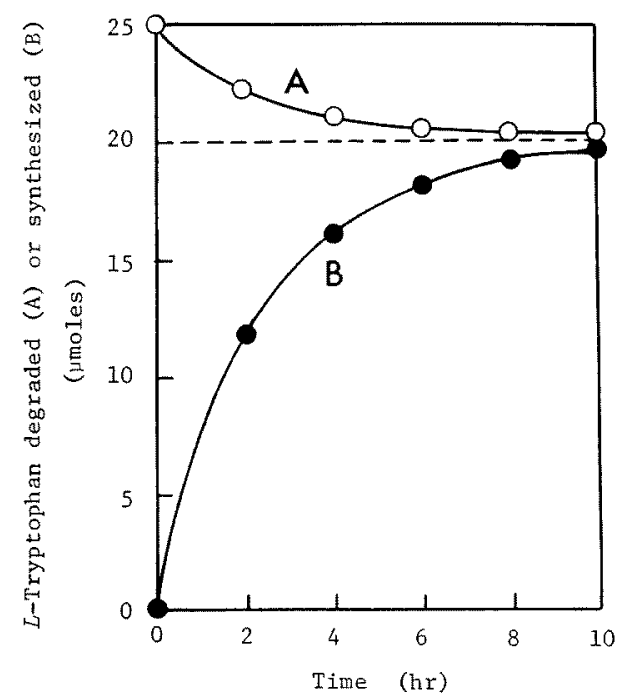

FIG. 4. Equilibrium of Elimination Reaction of L-Tryptophan by Cells of Proteus rettgeri.

The degradation reaction (A) was carried out at $37^{\circ} \mathrm{C}$ in a reaction mixture containing $25 \mu$ moles of L-tryptophan, 650 umoles of ammonium acetate, $8 \mu$ moles of $\mathrm{Na}_{2} \mathrm{SO}_{3}, 8 \mu$ moles of EDTA, $0.4 \mu$ mole of pyridoxal phosphate and $4.0 \mathrm{mg}$ of cells in a total volume of $1 \mathrm{ml}$ ( $\mathrm{pH}$ adjusted to 9.0 with $6 \mathrm{~N}$ $\mathrm{KOH}$ ). The synthetic reaction (B) was carried out at $37^{\circ} \mathrm{C}$ in the same reaction mixture as that of the degradation reaction, except that $25 \mu$ moles of L-tryptophan was replaced by $25 \mu$ moles of sodium pyruvate and $25 \mu$ moles of indole.

activity was examined in the presence of high concentration of ammonia. The result shown in Fig. 4, indicates that the equilibrium inclines toward synthetic state at a level of approximately 80 molar \%.

Synthesis of 5-hydroxy-L-tryptophan and 5methyl-L-tryptophan

When 5-hydroxyindole or 5-methylindole was substituted for indole in the standard reaction mixture, 5-hydroxy-L-tryptophan or 5-methyl-L-tryptophan was synthesized (Table IV) as shown by paper chromatography, and elution time on the automatic amino acid analyzer. In each respect, the product behaved identically with authentic 5-hydroxy-Ltryptophan or 5-methyl-L-tryptophan. How-
TABle IV. SYNTHESIS OF 5-HydROXY-L-TRYPTOPHAN AND 5-MeTHYL-L-TRYPTOPHAN BY CELls of Proteus rettgeri

The assay mixture containing $20 \mathrm{mg}$ of each substrate as indicated, $30 \mathrm{mg}$ of sodium pyruvate, $50 \mathrm{mg}$ of ammonium acetate, $1 \mathrm{mg}$ of $\mathrm{Na}_{2} \mathrm{SO}_{3}, 3 \mathrm{mg}$ of EDTA, $0.1 \mathrm{mg}$ of pyridoxal phosphate and $4 \mathrm{mg}$ of intact cells in a total volume of $1 \mathrm{ml}(\mathrm{pH} \mathrm{9.0),} \mathrm{was}$ incubated at $37^{\circ} \mathrm{C}$ for $16 \mathrm{hr}$.

\begin{tabular}{llc}
\hline \multicolumn{1}{c}{ Substrate } & \multicolumn{2}{c}{ Amino acid synthesized } \\
& & $(\mathrm{mg} / \mathrm{ml})$ \\
\hline Indole & L-Tryptophan & 11 \\
5-Hydroxyindole & 5-Hydroxy-L-tryptophan & 8 \\
5-Methylindole & 5-Methyl-L-tryptophan & 5 \\
Sodium sulfide & - & 0 \\
2-Mercaptoethanol & - & 0 \\
$\mathrm{H}_{2} \mathrm{O}$ & - & 0 \\
\hline
\end{tabular}

TABLE V. Synthesis of L-TRYPTOPHAN BY Cells of Proteus rettgeri

The assay mixture containing $30 \mathrm{mg}$ of each substrate as indicated, $20 \mathrm{mg}$ of indole, $50 \mathrm{mg}$ of ammonium acetate, $1 \mathrm{mg}$ of $\mathrm{Na}_{2} \mathrm{SO}_{3}, 3 \mathrm{mg}$ of EDTA, $0.1 \mathrm{mg}$ of pyridoxal phosphate and $4 \mathrm{mg}$ of intact cells in a total volume of $1 \mathrm{ml}\left(\mathrm{pH} \mathrm{9.0)}\right.$, was incubated at $37^{\circ} \mathrm{C}$ for $16 \mathrm{hr}$.

\begin{tabular}{lc}
\hline \multicolumn{1}{c}{ Substrate } & $\begin{array}{c}\text { L-Tryptophan } \\
\text { synthesized } \\
(\mathrm{mg} / \mathrm{ml})\end{array}$ \\
\hline Pyruvic acid & 14 \\
S-Methyl-L-cysteine & 17 \\
S-Ethyl-L-cysteine & 15 \\
L-Cysteine & 8 \\
L-Cystine & 5 \\
L-Serine & 5 \\
D-Serine & tr. \\
D-Tryptophan & $0{ }^{a\}}$ \\
5-Hydroxy-DL-tryptophan & 1 \\
5-Methyl-DL-tryptophan & 2 \\
5-Fluoro-DL-tryptophan & 6 \\
Oxalacetic acid & 10 \\
DL-Threonine & 0 \\
\hline a) Determined by microbiological method with & \\
\hline Lettconostoc mesenteroides. ${ }^{6}$. &
\end{tabular}

ever, when indole was replaced by hydrogen sulfite or methyl mercaptan, no synthesis of L-cysteine or S-methyl-L-cysteine was recognized. 


\section{Synthesis of L-tryptophan}

$\beta$-Replacement reactions [3] are shown to be catalyzed by tryptophanase., ${ }^{2,3,14}$ The synthesis of L-tryptophan from various amino acids and indole via $\beta$-replacement reaction was examined with the cells of Proteus rettgeri. L-Tryptophan was synthesized from indole and S-methyl-, S-ethyl-L-cysteine, L-cysteine, L-cystine, L-serine, 5-hydroxy-, 5-methyl- or 5-fluoro-DL-tryptophan (Table V). Oxalacetate also reacted, in the presence of high concentration of ammonia, with indole to synthesize L-tryptophan. It can be assumed that oxalacetate may be converted to pyruvate and $\mathrm{CO}_{2}{ }^{15}$, under the reaction conditions, then pyruvate formed interacts with ammonia and indole to synthesize L-tryptophan. No synthesis of L-tryptophan was observed with indole and $\mathrm{D}$-form of the amino acids.

Acknowledgement. We thank to Dr. T. Tsunoda and Dr. M. Takahashi, Directors of the Central Research Laboratories, Ajinomoto Co. Inc., for their encouragement during the course of this work. We also thank to Dr. Y. Kanaoka, Department of Pharmacology, Hokkaido University, Sapporo, for his kind gift of indole derivatives and to Miss K. Horinouchi for her assistance in the amino acid determinations.

\section{REFERENCES}

1) W. A. Wood, I. C. Gunsalus and W. W. Umbret,
J. Biol. Chem., 170, 313 (1947).

2) W. A. Newton and E. E. Snell, Proc. Nat. Acad. Sci. USA., 51, 382 (1964).

3) W. A. Newton, Y. Morino and E. E. Snell, J. Biol. Chem., 240, 1211 (1965).

4) H. Kumagai, H. Yamada, H. Matsui, H. Ohkishi and K. Ogata, ibid., 245, 1767 (1960).

5) H. Kumagai, H. Yamada, H. Matsui, H. Ohkishi and K. Ogata, ibid., 245, 1773 (1970).

6) H. Kumagai, H. Matsui, H. Ohkishi, K. Ogata, H. Yamada, T. Ueno and H. Fukami, Biochem. Biophys. Res. Commun., 34, 266 (1969).

7) T. Ueno, H. Fukami, H. Ohkishi, H. Kumagai and H. Yamada, Biochim. Biophys. Acta, 206, 476 (1970).

8) H. Kumagai, N. Kashima, H. Torii, H. Yamada, H. Enei and S. Okumura, Agr. Biol. Chem., 36, 472 (1972).

9) H. Yamada, H. Kumagai, N. Kashima, H. Torii, H. Enei and S. Okumura, Biochem. Biophys. Res. Commun., 46, 370 (1972).

10) T. Watanabe and E. E. Snell, Proc. Nat. Acad. Sci. USA, in press.

11) H. Yamada, H. Yoshida and T. Utagawa, Proceedings of the Annual Meeting of Agricultural Chemical Society of Japan, 1972, p. 104.

12) I. Smith, Nature, 171, 43 (1953).

13) T. E. Friedemann and G. E. Haugen, J. Biol. Chem., 147, 415 (1943).

14) Y. Morino and E. E. Snell, ibid., 242, 2800 (1967).

15) L. O. Krampitz and C. H. Werkman, Biochem. J., 35, 595 (1941).

16) G. Tamura, T. Tsunoda, J. Kirimura and $M$. Miyasawa, Nippon Nôgeikagaku Kaishi, 26, 464 (1952). 